the C.I.F. Salary Survey were mentioned as a model for all professional associations in Canada. Pamphlets on employment and earnings of the different professions were sent to all Section Representatives.

General day-to-day correspondence is still heavy. There are more high school students inquiring on the profession of forestry and more foresters from different countries inquiring on possible openings in the various phases of forestry in Canada.

J. J. E. Dosne

\title{
NEWS OF THE SECTIONS NEWFOUNDLAND
}

This report deals mainly with the proceedings of the 1961 Annual Section Meeting held in Corner Brook on November 23 and 24.

Some 30 delegates and guests representing the two paper companies (A.N.D. and Bowaters) as well as the Provincial Dept. of Mines, Agriculture and Resources and the Dept. of Education, Memorial University and several delegates from the Federal Department of Forestry attended the two day meeting. A special guest was Mr. Hans Lindberg, Woodlands Manager of Nova Scotia Pulp Ltd.

Following a brief business session the main part of the agenda consisting of two panel discussions and a number of very interesting papers was dealt with.

Two papers had as their central theme the balsam woolly aphid. One dealt with the spread of the insect in Nfld. in 1961 while the other discussed decay studies on aphid killed trees. A third paper reviewed the reforestation research done by the Dept. of Forestry in Nfld. while the fourth and final one concerned the woodlands operations of Nova Scotia Pulp Ltd. This last item was well illustrated with colored slides and presented by Mr. Lindberg.

All papers were ably presented and evoked considerable comment and discussion following their deliveries.

Two panel discussions related to the 1961 forest fires in Nfld. were the remaining items on the technical part of the program. One concerned the problems which would be created in the utilization of fire-killed pulpwood while the other was concerned with lessons learned and difficulties encountered in fighting the 1961 fires.

The second discussion group was composed of industrial and government personnel who had been intimately connected with the suppression of the fires in question.

The panel discussions proved to be highly interesting as each prompted considerable delegate participation.

The main item arising from the business session was the unanimous support given by the delegates to a resolution which stated that "a working committee be set up, perhaps under the sponsorship of the Newfoundland Forest Protection Association, to include representatives of the Federal and Provincial government and the forest industries. The purpose of this committee would be to set up a method of procedure acceptable to the parties concerned and to take prompt action to minimize the destructive effect of the balsam woolly aphid". 
It was subsequently moved and seconded and approved that an executive committee of the Section bring this resolution to the attention of the Minister of Mines, Agriculture \& Resources at the earliest opportunity.

Statistics presented at the meeting showed that a modest increase in membership had taken place since the 1960 meeting and that the membership had doubled since the Section was organized in 1956.

On the recreational side, delegates and guests were tendered a social hour and dinner by Bowaters Newfoundland Pulp and Paper Mills Ltd. The vicepresident and general manager of the company was the after dinner speaker.

\section{Nova Scotia}

W. A. Dickson

In 1944 the Nova Scotia members of the Canadian Society of Forest Engineers submitted to the Provincial Government a brief entitled "Forestry, Economy and Post-War Reconstruction in Nova Scotia." Most of the recommendations in that brief have since been implemented by the Province. Encouraged by this success, the Nova Scotia Section of the C.I.F. is now completing another brief, committee work on which was started about two years ago.

This brief was the main subject of discussion of the 1961 annual meeting of this Section, held in Halifax, November 29--December 1 under the chairmanship of R. R. Murray. Committee reports included those on wild life by A. T. Fraser, Utilization by G. R. Maybee and public relations by F. L. Gray. The report on mensuration by R. M. Bulmer included the recommendation of the adoption of a statutory Nova Scotia log rule and a re-inventory of the forest resources of the Province to be started in 1963, which is ten years after the start of the first Provincial inventory.

There was a panel discussion of the contentious subject of forest taxation which is probably a more serious problem in Nova Scotia than anywhere else in Canada. Chaired by J. S. Donaldson, this panel was composed of W. E. Moseley, Deputy Minister of Municipal Affairs; H. S. MacGlashen, Provincial Director of Assessment; L. S. Hawboldt and R. S. Johnson. Two forest tax systems are under consideration by the Section for recommendation to replace the present ad valorem tax system. These are taxation based on productive capacity assessment and a forest yield tax similar to that of the State of New Hampshire.

Forest legislation to replace Nova Scotia's Small Tree Act was recommended and a resolution concerning this has been presented to the Province. It is recommended that the Small Tree Act be repealed and a new Act be implemented to require reporting of all logging operations by land owners prior to cutting. This is recommended as a temporary measure (five years), to be followed probably by cutting practice legislation to provide for satisfactory forest regeneration.

\section{Maritime}

R. S. JOHNSON

A meeting of the Council of the Section was held January 27th, 1962. E. S. Fellows reported on the Directors' Meeting held as part of the C.I.F. Annual Mceting in Minneapolis. 
A tentative 1962 program was prepared. This will include the Spring Meeting to be held March 9th, 1962. The 1962 graduation class of foresters from the University of New Brunswick will be invited to attend. The theme of the meeting will be "The Agricultural Redevelopment Act".

A working committee was appointed to study employment prospects for graduates this year. A further, long range, study will be carried out on jobhiring procedures of government and industry.

The exchange of forestry publications with foreign countries by the Section is to be investigated and a list of members capable of translating various languages is to be prepared. Translations of content lists of publications received by members of the Section will be indexed in local libraries.

A curling bonspeil, to be called the "Annual Ring", will be held February 24th, 1962 at the Capital Winter Club, Fredericton. This is the result of a challenge by the Nova Scotia Section members to the Maritime Section. Skips representing Nova Scotia will be R. H. Burgess and R. R. Murray. Maritime Section skips will be T. M. Pond and W. Townsend. The trophy, a carved $\log$ cross-section, was made by $R$. C. Clark, a member of this Section.

\section{SAGUENAY}

JoHn P. Francis

The annual business meeting of the Saguenay Section was held at Chicoutimi on December 2, 1961.

The meeting was concerned strictly with business, and no technical session was held.

It was explained to those present that a meeting had been scheduled to be held in Dolbeau on September 30, 1961. Unfortunately, the council had decided to cancel this meeting. This was no reflection on the efforts of Lloyd Little, who had concluded arrangements which looked as if they would produce a very interesting time for anyone who was able to attend. As the date of the meeting approached, it became clear that there were too few members who were able or willing to go to make it worthwhile. This was due, not so much to a lack of enthusiasm, as to a regrettable combination of circumstances. Sickness, and unexpected duties connected with their jobs, prevented several of the members, who had already signified their intention of going to the meeting, from attending. Faced with this, the council took the only reasonable decision.

The December meeting was relatively short but productive; much important business was disposed of.

In the evening, in keeping with what seems to be a tradition in the Saguenay Section, the members and their ladies had dinner at a local hotel.

\section{QUEBEC}

D. B. MunN

Traditional bush fare served to a large gathering of members for the second regional meeting at Quebec city on November 29th predisposed members to a profitable evening's discussion of technical subjects. Prior to dinner at the Federal Forest Research Laboratory, Dr. L. Daviault and D. E. Etheridge steered the group on an inspection of the installations, and very informative comments and displays were given by Mr. Etheridge on his work on Stereum sanguinolentum. 
Following a business session, members explored the problems of rehabilitating abandoned agricultural land. This was timely in view of the findings of a recent survey conducted by Professors G. Ladouceur and M. Grandtner of Laval University which revealed close to $1 \frac{1 / 2}{2}$ million acres of privately-owned, abandoned farmland requiring treatment in the Southern part of the province.

Bob Blais used his experience skilfully in guiding discussion of the status of aerial spraying in the control of insect outbreaks. There was general agreement that spraying is a last-resort treatment for a problem whose roots lie in the fields of silviculture and management.

Members attending the second regional meeting in the Montreal area on December 8th at Macdonald College were welcomed by our Secretary-Manager, J. J. E. Dosne, at the new C.I.F. Head Office. Jim conducted a tour of the facilities. At the Pruche Chalet in the Morgan Arboretum, Dr. W. H. Brittain, former Dean at Macdonald, was on hand to welcome the members and to outline the history and development of the Department of Woodlot Management at Macdonald since its inception in 1956.

Thanks are due to Mr. A. R. C. Jones of the Department of Woodlot Management for his hosting of the members. During the evening Lowell Besley gave an account of the C.I.F.-S.A.F. meeting in Minneapolis.

Jim Dosne and R. E. (Rob) Keen are preparing to judge the Intercollegiate Woodmen's Competition at Macdonald College. Teams from the Forestry Faculties of Laval University, University of New Brunswick and University of Toronto and from Dartmouth, Middlebury and Paul Smith Colleges will compete.

F. A. Harrison has been appointed Chairman of the C.I.F. permanent Building Committee and is to select members to serve on his team.

\section{Algonquin}

J. M. Conway

The November meeting of the Algonquin Section of the Institute was held at the Copeland Hotel in Pembroke on November 28, 1961.

The theme of the meeting was white pine weevil, a topic of considerable interest to Foresters and laymen alike in this part of the Ottawa valley where white pine plays such an important role in the local economy.

The guest speaker of the evening was Mr. C. R. Sullivan, Research officer at the Forest Insect Laboratory, Sault Ste Marie, Ontario, who spoke on the studies being conducted toward developing possible cutting methods to control White Pine Weevil.

Mr. W. Stiell of the Petawawa Forest Experiment Station, who has been concerned with the application of Mr. Sullivan's findings in practical silviculture outlined the work that has been done in this regard.

Mr. K. T. Logan of the Petawawa Forest Experiment Station, also involved in white pine weevil control research, described his work on the shading and growth rate of white pine, which are factors in weevil control.

The members were fortunate in having such a well informed group of speakers on a subject of such vital concern to the area represented by the Algonquin Section.

R. John Hall 


\section{Central Ontario}

Members attending the Central Ontario Section meeting at North Bay on December 9th enjoyed the unusual experience of touring the S.A.G.E. installation currently under construction in that area. The visit was under the auspices of the R.C.A.F.

A business meeting preceded the tour and it included a brief review of committee activities and a report by section representative Bill Clarke outlining the proceedings of the council meeting at Minneapolis last fall.

G. R. MORRISON

\section{SOUTHERN ONTARIO}

A panel discussion providing an evaluation of the Resources for Tomorrow Conference was the feature of the November meeting. Panelists were:

Dr. Howard Patterson, Director, Farm Economics and Statistics Branch, Ontario Department of Agriculture.

Mr. D. N. Ormand, Supervisor, Wildlife Section, Ontario Department of Lands \& Forests.

Professor D. V. Love, Faculty of Forestry, University of Toronto.

Mr. R. W. A. Thomson, Chief Forester, Ontario Division, Ontario Paper Company.

The moderator, Dr. J. W. B. Sisam, after giving an outline of the purpose, origin, organization, and objectives of the Conference, introduced the members of the panel, giving a brief description of the activities each member of the panel had participated in at the Conference.

The individual speakers commented on the Conference discussions in relation to their own fields of interest. A spirited question period followed. The forestry question causing the most discussion was the reason for the lack of press coverage on forestry topics at the Conference.

One of the two features of the December meeting was the report presented by Mr. K. A. Armson, Section Representative on the Board of Directors, of the Directors' meeting held in Minneapolis in September. There was considerable discussion of the move of the Head Office from Toronto to Montreal. and the possible building of a permanent headquarters. The following motion, evolving from the discussion, was passed unanimously and forwarded to Head Office and to all Section Chairmen.

Moved: "That the Canadian Institute of Forestry is neither large enough nor wealthy enough to construct and maintain a permanent headquarters building.

Further, it is the opinion of this Section that the Head Office should be located in Ottawa upon the expiry of the agreement with Macdonald College. Quarters in Ottawa could possibly be shared with other professional groups."

The second feature was a talk by Mr. Keith Horton, Research Forester, Department of Forestry, on white pine management. The main theme developed by Mr. Horton was that satisfactory natural regeneration of white pine could be obtained at reasonable costs if certain factors of silviculture were recognized and provided for in cutting plans. The speaker demonstrated this theme by using slides taken in the main white pine areas of Ontario. 
At the January meeting, Mr. Ross Silversides, Research Forester, Abitibi Power \& Paper Company, gave his impressions of the 13th Congress of the International Union of Forest Research Organizations held in Vienna last September. In his talk, Mr. Silversides gave a brief account of the group's history, aims, and organization. He also presented an informative, illustrated talk on a forestry field trip during his visit to Switzerland prior to attending the Congress.

F. M. BUCKINGHAM

\section{NORTHERN ONTARIO}

The 144th meeting of the Section was held at the Kapuskasing Community Club, with Mr. L. C. Erwin as guest speaker. Mr. Erwin is Construction Engineer for the Ontario Hydro Commission. He spoke of the new power developments on the Mattagami River and their forestry ramifications. A LeTourneau Tree Crusher was used to clear some bush areas in the flood basin of Little Long Rapids, a Hydro project about 40 miles north of Smooth Rock Falls on the Mattagami River.

The Department of Lands and Forests, using an aircraft from Gogama is collecting black spruce scions from selected trees in Mann Township, an inaccessible area near the Frederickhouse River, about 10 miles north of Frederickhouse Lake.

\section{NORTHWESTERN ONTARIO}

F. N. RoBINSON

Our annual fall social for the Section was held at the Nor-Shor Motor Hotel, Port Arthur, on December 1st, with over 150 members, their wives and friends in attendance. A bountiful dinner and an enjoyable evening of dancing followed. The party was a financial success and the $\$ 127.00$ profit will be used to meet our Section's commitments to the Lakehead College Library and the Scholarship Fund.

On the evening of January 26th, the regular Section meeting was held at Club 17, Fort William. Mr. Ken Hearnden gave a very full report on the business meeting at Minneapolis, where he again represented the Section. Our plans for the next three months were also discussed.

\section{LAKE OF THE WOODS}

R. S. HYSLOP

A meeting was held in Dryden, Ontario on Saturday, Jan. 20, 1962. Sixteen members from Kenora, Fort Frances, Sioux Lookout, and Dryden attended.

In the absence of the Chairman and Vice-Chairman, W. F. Beatty conducted the meeting.

The Nominating Committee presented the following slate of ofticers for the coming year:

Chairman-L. Paterson, Vice-Chairman-W. F. Beatty, CouncillorsGeo. Garner, H. J. Henry, and J. L. Mullen. Section RepresentativeH. A. Coles.

F. E. Sider is leaving Kenora; so a new Chairman of the Membership Committee, George Garner, was appointed to replace him on this Committee. 
J. E. "Barney" Barnes gave a talk on the fire situation in the Sioux Lookout District in the disastrous summer of 1961 . He also showed a movie that he had taken last summer of several of the fires.

W. F. BEATTY

\section{MANITOBa}

Approximately 30 members attended a dinner meeting held in Winnipeg on December 6th at which Dr. Graham Cooch of the Canadian Wildlife Service was guest speaker. Dr. Cooch gave an illustrated talk on his ecological studies of the blue goose. The geese breed in 13 colonies located in Northern Canada and Siberia. The breeding season averages 95 days, with a maximum of 105 days. It was pointed out that the poorer the breeding season, the better the hunting in Manitoba and the northern states. In years with good breeding seasons the birds develop to such an extent that they can fly non-stop from Hudson Bay to Louisiana and Texas. Just a 4-day delay in the breeding season can result in one-half of the geese landing in Manitoba or northern U.S.A. Dr. Cooch mentioned the possibility of managing blue geese on the basis of data obtained directly on the breeding grounds.

The speaker also discussed some effects of herbicides, insecticides, and pesticides on fish and wildlife and emphasized the need for ecological studies of fish, birds and animals in connection with spraying operations.

Twenty-four members attended a meeting at Molson's Brewery in Winnipeg on January 25th. At that time a committee was set up to present a report to the Section Annual Meeting regarding a motion (26:61, For. Chron., Dec. 1961, p.441) presented to the C.I.F. Annual Meeting at Minneapolis. This motion was concerned with C.I.F. participation in a program of "Technical Assistance to Underdeveloped Nations in the Western Hemisphere". A second committee is to be established to prepare a brief dealing with the development of primary forest industries in Manitoba. This brief will be submitted to the Forestry Group of the Committee on Manitoba's Economic Future. Following the business, refreshments were provided through the courtesy of Mr. Chiswick, Sales Representative.

The Annual Meeting of the Section will be held on April 13th and 14th and its theme will be "Fire, Including Prescribed Burning". For September a joint meeting with the Saskatchewan Section is planned. It will be held somewhere in western Manitoba.

J. H. CAYYORD

\section{SASKATCHEWAN}

At the Saskatchewan Section meeting of the C.I.F., which was held on Friday, September 22nd, C. L. Kirby was elected Vice-Chairman and A. Kabzems was elected a Councillor.

D. L. Golding gave an informative slide talk on his tour of Southern American Forest Experimental Stations and Dr. M. Timonin gave an interesting talk on micro flora at the meeting. 
At the C.I.F. meeting on Friday, November 17th, Dr. Kupsch, who is a geologist with the University of Saskatchewan, gave an illustrated talk on land forms. The talk was followed by a lively question period.

W. S. Bailey, our representative at the C.I.F. Board of Directors meetings held recently at Minneapolis, gave a report on the happenings there.

D. R. CUTLER

\section{ROCKY MounTaIN}

The Rocky Mountain Section held its winter meeting on February 2 and 3, in Edmonton. A business meeting and banquet were held the first day, and a technical session the second.

Guest speaker at the banquet was Mr. M. Joonson, consultant to the Alberta Government on personnel administration, and member of the Faculty of Commerce at the University of Alberta. Mr. Joonson described the problems of land use and conservation in Venezuela. The economy there is based on oil, and the progressive government is turning the money back into the development of new or stronger existing industries. Basic land reform is a primary requisite in this country where 82 per cent of the farm area is held in 2.5 per cent of the farm units. A water resource policy and rural planning are necessary to stop the clearing of steep mountain slopes for short term farming.

With a literacy rate of only about 40 per cent, education is of primary importance if the people of Venezuela are to raise the level of their living standards. Oil and undeveloped iron ore make this nation a political "plum" and subject to world politics and strife.

Stan Jobb was moderator for the technical session of the meeting. Gordon de Grace spoke on the application and theory of variable plot cruising as employed by the Alberta Forest Service. Stand and stock tables are being developed by measuring the "in" trees as shown by the prism cruise. With the prism being used to set the plot radius, more weight is given to the sample of the larger trees in the stand.

Roy Shepherd presented a paper on the use of sequential sampling in forest insect and regeneration surveys. This technique can result in great savings in time and cost with no loss of accuracy if a suitable method of plot location is employed.

Results of nine months' experience using a tape recorder in cruising were reported by Jack Wright. Features of the design of the recorder that facilitate use in the field were outlined. Tallying in cold or rainy weather is simplified by using a recorder with the resulting reduction in loss of field time.

E. H. Lyons of the B.C. Forest Service spoke on the use of helicopters in cruising, stand classification, and low level aerial photography. Savings of up to 50 per cent in time were realized by moving field crews by helicopter. Accuracy of the cruises is possibly better and morale is much improved over the old methods of walking and boating.

Stands are classified by making two passes over the predetermined points with the observer recording information on a tape recorder. Low level 
photographs are taken simultaneously with two cameras mounted below the helicopter. A $70 \mathrm{~mm}$ format on black and white reversible film is used, thus enabling the photos to be viewed in stereo as slides instead of prints.

A forestry career guidance pamphlet has been prepared by members of this section and will be published by the Alberta Government.

Des Crossley has advised me that, contrary to my last submission, he is not predicting seed crops, but building up statistics on seed crop periodicity and concomitant viable seed yield.

Glen Paul

\section{CARIBOO}

At our November meeting, Mr. L. A. (Bud) Smithers of the Federal Department of Forestry outlined their work and expressed hopes that close cooperation will develop between his department and the C.I.F.

Harvey Anderson gave a short report on his trip to the joint meeting at Minneapolis.

Bob Wood presented a report of the Regeneration Committee, the results of three years of committee work.

At our December meeting the report of the Regeneration Committee was discussed, and a Steering Committee was formed to promote better regeneration in the area. Members of this committee are John Frey, Bob Wood, Phil Bodman, and Art Prochneau.

The Cariboo Section of the C.I.F. provided a trophy to be awarded annually to the most proficient Junior Forest Warden group in this area.

At our January meeting there were further discussions on regeneration problems. It was decided to prepare a brochure on ways and means of solving the regeneration problems.

On January 25th approximately 15 members of the Cariboo Section attended the annual meeting of the Association of British Columbia Foresters at Kamloops, B.C. The next day a joint meeting of all five sections of the C.I.F. in B.C. was held in Kamloops. The main topic at this meeting was the need for closer ties and better co-operation between the five sections. It was resolved that following each annual A.B.C.F. meeting a joint provincial C.I.F. meeting be held. A British Columbia C.I.F. Council was formed, its members being the chairmen of the five C.I.F. sections in B.C.

Our February meeting is planned to be held in Smithers.

\section{November 14}

\section{VANCOUVER}

GEORGE KONDOR

John Billings, President of B C's Forest Industrial Relations, and Joe Morris, President of the Western Canadian Regional Council No. 1 International Woodworkers of America, have seldom had the opportunity of appearing together before a more unbiased audience than on the evening of November 14, when the two were on a panel at a well-attended dinner meeting of the Vancouver Section. 
Usual meetings of the two men start on March 15 each year, when they begin negotiations for the year's labor-management contract. The period for negotiations was first established in 1943.

Moderator of the panel on "Labor Problems in the B.C. Woods" was Professor H. C. Wilkinson, of the University of B.C. Faculty of Commerce and Business Administration. He set the stage for the evening by explaining that discussions were to be limited to the B.C. Coast.

F.I.R. represents 125 wood-products companies of the Coast on labor matters and has done so for 20 years. Five of the F.I.R. companies are integrated ones, but F.I.R. does not handle their pulp-and-paper labor problems. Mr. Morris, on the C.I.F. panel, spoke for eight local I.W.A. unions of the B.C. Coast, representing 18,000 men in logging camps and conversion plants.

Mr. Morris said that the productivity increase in the industry was the reason for the unions' usual demand at the negotiating table for an increase in wages. He also contended, "The rising cost of living never appears on companies' balance sheets."

Mr. Billings pointed out that the export trade in wood products is of the greatest importance on the B.C. Coast; that increased costs in it cannot be passed on to customers, as in the construction or public-utility industries to which the I.W.A. often makes comparisons. "The record-breaking woodproducts shipments of the last two years have hardly been worthwhile profitwise," he said. "Some of our companies are losing money."

\section{December 12}

Thirty-five members and one guest braved Vancouver's first snowfall of the winter on the evening of December 12, 1961, to hear a program featuring Dr. Miles Gibson, recently retired Dean, Faculty of Forestry University of New Brunswick.

The retired dean, who has joined the University of British Columbia Faculty of Forestry for the spring term, spoke on "Forestry in the Maritime Provinces." He said the provinces of New Brunswick, Nova Scotia, Newfoundland and Prince Edward Island contain 9.7 per cent of the forest land and between nine and 10 per cent of the growing stock in Canada. Roughly half of their area is forest land.

Highlights of the speech include: disastrous forest fires of last summer call for a better forestry organization in Newfoundland, where there is no stumpage payment to the government to finance same. In places one can find four sets of stumps in the forests of Nova Scotia and New Brunswick, representing four different logging cycles on the same area since first settlement. There is not yet a saturation of pulp mills in the Maritimes as far as wood supply is concerned.

Accessibility is no problem in the forests of N.B. and N.S., 70 per cent of the latter being in seven ownerships, but there are also several thousand small owners in each province. Ninety per cent of N.B. forests are covered by management plans, licences for many of which areas expire in 1963. Dr. Gibson indicated that N.B. might institute something comparable to the Tree Farm Licenses of B.C., when the present licences expire. 
Neither forest fire nor regeneration of cut-over land are great problems, he said, but control of the spruce budworm is a major one. The last has called for the aerial spraying of seven million acres at a cost of approximately one dollar per acre.

Section delegate to the C.I.F.-S.A.F. convention in Minneapolis, Walter Tuttle, gave a good account of the annual C.I.F. directors' meeting and the annual meeting. William McGhee, C.I.F convention chairman for 1962, gave a brief report on the progress made by his committee.

January 9

Problems caused by the conflict of interests between the growing "Forest-recreation explosion" and timber growing in B.C. took top billing in a panel discussion at the January 9 meeting.

Theme of the discussion, moderated by Dr. J. H. G. Smith of the UBC Faculty of Forestry and C.I.F. Editor was multiple use of forest lands in B.C. "Irresponsible" people, who set fires and shoot up machines in the woods, drew the most fire during the evening.

Panel members were: Ian Cameron, District Forester, Vancouver Forest District, B.C. Forest Service; Harold McWilliams, Director, B.C. Parks Branch, Department of Recreation \& Conservation, Victoria; Hugh Hodgins, VicePresident, Timber, Crown Zellerbach Canada Ltd. and immediate past president of the national C.I.F. organization; Alf Buckland, Forest Engineer, Canadian Forest Products Ltd. All of the men are section members except McWilliams, who belongs to the C.I.F. Vancouver Island Section.

Each panel member and the moderator had a different definition of forest "multiple use," but most of them included both "two or more objectives" and "one use predominates".

Mr. McWilliams foresaw that the B.C. Forest Service will have to get back in the recreation business. He also said, "If it is considered necessary to practice multiple use in B.C. parks, those areas shouldn't be parks". His branch was divorced from the forest service on April 1, 1957.

For instance, Mr. McWilliams said, there are two thousand new anglers in B.C. each year. He and other panel members quoted many other statistics, mostly from the U.S.A., bearing on the magnitude of the recreational problem facing foresters.

Mr. Cameron, in administration of his busy forest district, has encountered no real recreational problems yet.

Mr. Hodgins spoke of the elaborate precautions taken by his company to supervise public entry to and use of its lands, including gates, gatemen and entry permits. He summed up by saying, "There is not enough government recognition of the responsibilities that companies must assume for public use on lands of private tenure".

Mr. Buckland pointed out that everybody present at the meeting was present because of the B.C. timber business. His contention was, "Planned logging is beneficial to all forest users, even recreationists."

\section{Annual Meeting}

Organizing committees for the Vancouver Section's 1962 convention held their second general meeting on January 31. All committees have been working on their respective phases of the five-day national meeting. 
L. B. B. Boulton, Assistant District Forester of the Vancouver Forest District, B.C. Forest Service, has been chosen to head the Field Trips and Tours Committee, since its former chairman has been transferred to Vancouver Island. Mr. Boulton has planned trips to the Mission City Tree Farm Licence, the University of B.C. Research Forest, the Squamish area, local wood-processing plants, and Vancouver Island. ary 28 .

Budget estimates on the basis of 350 delegates are to be made by Febru-

An additional committee, one for displays, has been organized by W. G. Burch, Chief Forester of B.C. Forest Products Ltd.

The Social Events Committee submitted a tentative convention program and, after numerous changes at the meeting, it was released for publication below.

ROBERT H. Forbes

Proposed Schedule for 1962 Annual Meeting of C.I.F. at Vancouver

Sanday, October 21

Meeting of Board of Directors.

Registration Begins.

Monday, October 22

Registration Continues.

9:30 a.m.-12 noon Official Opening.

Including an address by the Minister of Lands and Forests for B.C.-Hon. R. Williston.

Noon Official Luncheon.

1:30 p.m.-4:30 p.m. Technical Sessions begin on "Conflicts in Forest Use". Evening Informal.

Tuesday, October 23

All day Field Trips to logging operations and managed forest areas to illustrate conflicts in forest use.

Evening Informal.

Wednesday, October 24

9:30 a.m.-12 noon Technical Sessions Continue.

Noon Informal Alumni Luncheons.

1:30 p.m.-4:30 p.m. Technical Sessions.

Evening

Simultaneous Technical Standing Committee Meetings (tentative).

Thursday, October 25

9:30 a.m.-12 noon

Complete Technical Sessions.

1:00 p.m.-4:30 p.m. General Business Meeting. Including report by Na-

Evening tional Committee on Forest Economics and Policy. Banquet and Dance.

Sponsored by the Provincial Government of B.C. 